Historic, Archive Document

Do not assume content reflects current scientific knowledge, policies, or practices. 



\section{Retail Price List \\ Gladiolus Bulbs}

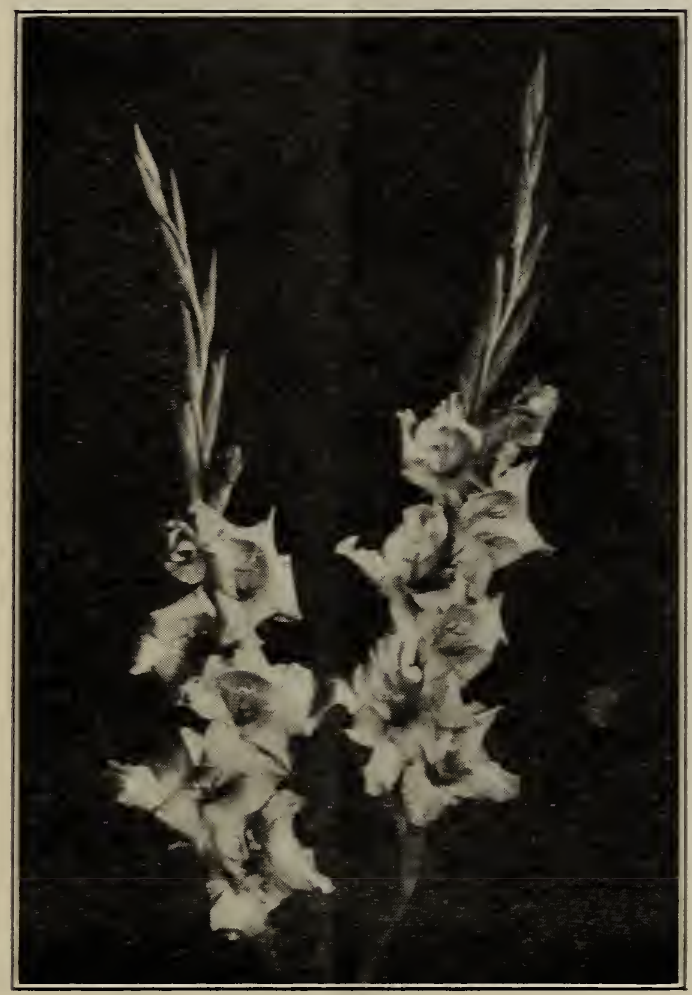

Warren Gladiolus Gardens James G. Warren

P. O. Box $38 \quad$ Frankfort, Indiana 


\section{The Gladiolus and its Culture}

The gladiolus is one of the most popular of all the garden flowers. In its variety and blending of colors it rivals the rainbow, and in its wide range of uses it cannot be surpassed by any flower. As a cut flower it has few equals. Cut as the first floret opens, it will last a week in hot weather, and longer in cooler weather. By daily changing the water, removing the withered flowers, and cutting off a portion of the stem, every bud will open and last lcnger than if left to bloom in the garden. Its lack of fragrance appears at first as its only fault, but this is a distinct advantage where the flowers are banked and for its use in the sick room.

It is one of the easiest of flowers to grow, thriving with ordinary care, and responding remarkably to intensive cultivaticn. Deep planting helps it to withstand heavy winds and drouth. Plant it in the open garden away from shade trees and buildings, cultivate after every rain or watering, fertilize sparingly, and you will be rewarded with beautiful flowers. Plant the bulbs at weekly intervals from the first of April to the first of July and the first will begin to bloom as the last is planted. By selecting several varieties one can thus have a successicn of bloom for nearly four months of the year!

The gladiolus is grown from seed, from bulblets, and from bulbs. Only the hybridizer is interested in raising it from seed as this takes longer to produce the flowers. The gardener can increase his stock by planting the bulblets, a few of which will bloom the first year and a majority the second year. The bulblet comes true to the parent bulb, but if the seeds are sown, new varieties are produced. The hybridizer does not depend upcn chance pollination, but selects the parent plants and does the crossing by hand. Anyone can produce a new variety in his own back yard if willing to follow the necessary details. For the beginner, however, it is better to plant the blooming size bulbs as these will produce the desired blooms the same season.

Blooming size bulbs vary from one to two or more inches in diameter, according to the variety and age of the bulb. Bulblets produce bulbs up to about one inch in diameter and these are known as planting sizes. Nearly all of these will bloom the second year and are then sold as mature bulbs. Bulblets form at the base of the new bulb, the difference between a bulblet and a small bulb being that the bulblet is always encased in a hard shell while the bulb is not. Bulbs of all sizes germinate easily but the main difficulty in growing from bulblets is to secure good germination. Commercial growers usually soak the bulblets in luke warm water for twenty-fcur hours previous to planting. This softens the shell and enables the sprout to break through. Bulblets are sown very thick, several hundred to the foot, while bulbs are planted from one to six inches apart, depending upon the size planted.

We offer three sizes for sale, all of which will blocm perfectly under normal conditions. Some growers are offering bulbs at cheaper prices, evidently one year stock from bulblets. The bulbs we offer are all two year old stock and have been tested for trueness to variety in our gardens. Size one bulbs are over $1 \frac{1}{2}$ inches in diameter; size two are from $1 \frac{1 / 4}{4}$ to $1 \frac{1}{2}$ inches, and size three are from 1 to $1 \frac{1 / 4}{4}$ inches. The only advantage in size one over size three is that many of the number one bulbs will produce two cr more spikes of flowers and two or more bulbs for the following year's planting. The smaller bulbs will usually produce more bulblets than the large ones so it amounts to about the same value either way. Personally, we would prefer number three bulbs and buy more of them. 


\section{An investment in Glads pays beautiful interest}

\section{Glad Information}

Our gardens are located one-half mile west of the city on the Blinn Gravel Road. The Lafayette Interurban goes by the place. Follow the car line to our sign, or, if you come on the car, get off at Stop 39 and walk west to the first house. Visitors are always welccme. August and September are the best months to see many varieties in bloom.

\section{THE AMERICAN GLADIOLUS SOCIETY}

This is a country-wide organization of glad fans with thousands of members. The dues are two dollars a year, for which each member receives "The Gladiolus Reriew", a monthly magazine "Devoted to the interests of Gladiolus growers and lovers." This year the annual meeting and show of the society will be held at Toledo, August 16 and 17. If interested, send us two dollars for enrollment, and plan to attend the show. The magazine alone is worth the membership fee.

\section{PRONUNCIATION OF GLADIOLUS}

This caused so much ccnfusion that the American Gladiolus Society, at its annual meeting at Rochester. New York. in 1925, roted unanimously to adopt one pronunciation and form of the word for all uses. The accepted pronunciation is glad-i-o'-lus for both singular and plural, or just say glads for short. You will surely say "oh!" when you see a choice variety in blocm for the first time, so accent the "o" when you pronounce the word.

\section{CULTURAL DIRECTIONS}

Complete directions for raising gladiolus will be included with every delivery of bulbs. These directions are standardized by the A. G. S. and cover erery phase of the work from planting of the bulbs to harresting and winter storage. The purchase of a few bulbs means years of pleasure to the grower who follows the simple directions and cares for the increase.

\section{OUR GUARANTEE}

We guarantee our bulbs to be up to size, true to name, and free from disease. We treat our bulbs at planting time to prevent disease, and we use every precaution to keep the varieties separate. We will refund the purchase price or replace the bulbs on any orders that do not measure up to our guarantee. The purchaser buys with the understanding that we will not be held liable for more than the original purchase price on any stock that proves untrue.

\section{DELIVERY OF BULBS}

Our prices include delivery by parcel post or express anywhere in the United States. We guarantee safe arrival of the bulbs after March 15. Local customers are urged to come for their bulbs as we will give extra bulbs for saving us the expense of packing and shipping. Our terms are cash on or before delivery. We offer no discounts, but prefer to give extra bulbs of varieties other than what you order, the larger the order the more extra bulbs of course. Order early before any varieties are out of stock, and we will deliver the bulbs when wanted.

\section{CUT FLOWERS FOR SALE}

Cutting the spike as the first flower is wide open aids in bulb derelopment as the strength of the plant then goes to maturing the bulb instead of ripening the seed. During the blooming season we sell flowers at the farm for 50 cents a dczen.

\section{BUY 'EM GLADS}

'Twere better to send a cheap bouquet

To a living friend this very day,

Than a bushel of roses, white and red,

To lay on his coffin when he is dead.-Holland. 
Six bulbs of a kind at dozen rate; 50 at hundred rate

ALICE TIPLADY (Kunderd)

$\mathrm{Si}$

with florists.

\section{ANNA EBERIUS (Diener)}

Dark velvety purple, deeper in throat, a grand variety.

CRIMSON GLOW (Betscher)

A rich glowing crimson as its name implies, one of the best reds.

\section{EVELYN KIRTLAND (Austin)}

Glistening pink, darker at the edges, shell pink center with scarlet blotches on the lower petals.

E. J. SHAYLOR (Kunderd)

A beautiful, pure, deep rose pink, of the ruffled type, extra fine.

FLORA (Velthuys)

Clear canary yellow, large blooms, well placed on a showy spike.

\section{GLORY OF KENNEMERLAND}

Deep rose, with golden yellow throat, wax-like blooms.

\section{GOLDEN MEASURE (Kelway)}

Large deep yellow flowers on a tall sturdy spike, generally considered the best commercial`yellow.

\section{HALLEY}

Early salmon pink, very popular with florists.

HERADA (Austin)

Pure mauve, glistening and clear, very popular.

\section{LE MARECHAL FOCH}

Light pink flowers of enormous size, early to bloom and splendid for cut flowers.

1
2
3

\section{Each}

.06

.05

.04

.05

.04

.03

1

.07

.06

.05

Dozen

.60

.50

.40

100

$\$ 3.00$

2.50

2.00

.50

.40

.30

.70

3.50

3.00

2.50

.50

5.00

1.00

4.00

2.50

.50

.08

.60

2.50

40

2.00

.80

$\begin{array}{ll}.07 & .70 \\ .06 & .60\end{array}$

3.50

3.00

3.00

.10

1.00

.08

.75

.05

.50

.06

.60

.50

.40

3.00

2.50

.05

2.00

$\begin{array}{ll}2 & .05 \\ 3 & .04\end{array}$

1.50

.15

1.00

.80

5.00

4.00

.08

.50

.05

.40

.30

2.00

.03

1.50

1

.06

.60

.05

.50

.04

.40

1 
You will be glad if you buy our glads

L'IMMACULEE (Velthuys)

Pure white, many lily-like blooms open at a time on a tall, graceful spike.

LOUISE (Wright)

Large lavender with wine color in throat, resembles an orchid.

\section{MRS. FRANCIS KING (Coblentz)}

Light scarlet with deeper orange markings, sturdy upright spike with many blooms open.

Size Each

$1 \quad .06$

$2 \quad .05$

3

.04

1

1

3

.10

.07

.06

.06

.05

.04

Dozen

.60

.50

.40

1.00

.70

.60

3.50

3.00

3

\section{MRS. FRANK PENDLETON}

$\begin{array}{llll}\text { (Kunderd) } & 1 & .07 & .70 \\ \text { Rose pink with bright red throat blotch, } & 2 & .06 & .60 \\ \text { an old farorite and a great prize winner. } & 3 & .05 & .50\end{array}$

\section{PRINCEPS (Vaughan)}

Brilliant scarlet crimson, with white blotch on each of the lower petals, especially fine as a landscape variety.

\section{SCARLET WONDER (Cowee)}

Mammoth deep scarlet flowers, a giant in height and size of blooms. Have only a few to spare.

\section{PRIMULINUS MIXTURE}

\section{(Kunderd)}

Smaller hooded type of gladiolus noted for slender, graceful spikes and the pastel shades. Early and prolific. Large bulbs produce several spikes.

\section{MIXTURE}

Contains many of the older named varieties, well worth the money. When any of our bulbs get mixed we put them in this mixture.

\section{RAINBOW COLLECTION}

One bulb each of twenty-five named varieties, our selection. $\$ 1.00$. Add fifty cents if you wish them separately labeled.

\section{GEM CITY COLLECTION}

One bulb each of twenty-five of the newer and choicer varieties, such as sell from $10 \mathrm{c}$ to $50 \mathrm{c}$ each. Each bulb separately labeled. We grew over one hundred varieties this year and have reserved the high. priced ones for this collection. 25 bulbs for $\$ 2.50$.

$\begin{array}{lll}.05 & .50 & 2.50 \\ .04 & .40 & 2.00 \\ .03 & .30 & 1.50\end{array}$

$\begin{array}{lll}.05 & .50 & 2.50 \\ .04 & .40 & 2.00 \\ .03 & .30 & 1.50\end{array}$




\section{STRAWBERRY AND RASPBERRY PLANTS}

We have had so many inquiries for strawberry plants that we have made arrangements to offer them to our customers through the O. A. D. Baldwin Nursery Company, of Bridgman, Michigan. We have been personally acquainted with $\mathrm{Mr}$. Baldwin for a number of years and know that he is reliable. $\mathrm{He}$ is one of the largest strawberry growers in the United States; and Bridgman is located in the famous fruit belt of western Michigan.
Prices of plants do not include delivery charges. Be sure to enclose sufficient postage for parcel post shipments and send us your order early. We cannot accept any plant orders later than the fifth of May. For Indiana figure all points north of Indianapolis in the second zone, and south, in the third zone. Send remittance in full for orders from this page and the plants will be sent to you direct from Bridgman under the Baldwin guarantee.

If no remittance for postage is included with the order, we will ship by express. From the table below you can readily determine the amount of postage required on your order:

\begin{tabular}{|c|c|c|c|c|c|c|c|c|}
\hline $\begin{array}{l}\text { Strawberries and Asparagus } \\
\text { Red Raspberries and Dewberry Tips } \\
\text { Black Raspberry Tips, Blackberries }\end{array}$ & $\begin{array}{l}1 \text { st } \\
2 \text { nd } \\
---\$\end{array}$ & $\begin{array}{l}\text { and } \\
\text { zone } \\
0.08 \\
.12 \\
.18\end{array}$ & $\begin{array}{r}3 \mathrm{rd} \\
\text { zone } \\
\$ 0.15 \\
.18 \\
.26\end{array}$ & $\begin{array}{l}4 \text { th } \\
\text { zone } \\
\$ 0.20 \\
.30 \\
.40\end{array}$ & $\begin{array}{r}5 \text { th } \\
\text { zone } \\
\$ 0.30 \\
.40 \\
.65\end{array}$ & $\begin{array}{r}6 \text { th } \\
\text { zone } \\
\$ 0.36 \\
.50 \\
.85\end{array}$ & $\begin{array}{r}7 \text { th } \\
\text { zone } \\
\$ 0.46 \\
.60 \\
.90\end{array}$ & $\begin{array}{r}8 \text { th } \\
\text { zone } \\
\$ 0.55 \\
.70 \\
1.00\end{array}$ \\
\hline $\begin{array}{l}\text { EXTRA EARLY } \\
\text { STRAWBERRIES } \\
\text { Charles I }\end{array}$ & $\begin{array}{r}\mathbf{P} \\
\mathbf{5} \\
\mathbf{5 0}\end{array}$ & $\begin{array}{l}\text { er } \\
50 \\
.55 \\
65\end{array}$ & $\begin{array}{l}\text { Per } \\
75 \\
0.70 \\
.85\end{array}$ & $\begin{array}{r}\text { Per } \\
100 \\
\$ 0.90 \\
1.00\end{array}$ & $\begin{array}{c}\text { Per } \\
200 \\
\$ 1.30 \\
1.50\end{array}$ & $\begin{array}{r}\text { Per } \\
300 \\
\$ 1.80 \\
2.00\end{array}$ & $\begin{array}{r}\text { Per } \\
400 \\
\$ 2.20 \\
21.60\end{array}$ & $\begin{array}{c}\text { Per } \\
1000 \\
\$ 5.00 \\
6.00\end{array}$ \\
\hline $\begin{array}{l}\text { MEDIUM EARLY STRAWBERRIES } \\
\text { Cooper } \\
\text { Dr. Burrill } \\
\text { Senator Dunlap }\end{array}$ & & $\begin{array}{l}.90 \\
.55 \\
.50\end{array}$ & $\begin{array}{r}1.20 \\
.70 \\
.65\end{array}$ & $\begin{array}{r}1.45 \\
.90 \\
.85\end{array}$ & $\begin{array}{l}2.15 \\
1.30 \\
1.25\end{array}$ & $\begin{array}{l}2.95 \\
1.80 \\
1.75\end{array}$ & $\begin{array}{l}3.70 \\
2.20 \\
2.15\end{array}$ & $\begin{array}{l}8.50 \\
5.00 \\
4.50\end{array}$ \\
\hline $\begin{array}{l}\text { UEDIUM LATE STRA WWBERRIES } \\
\text { Eaton } \\
\text { Booster }\end{array}$ & & $\begin{array}{l}.60 \\
.95\end{array}$ & 1.25 & $\begin{array}{r}.95 \\
1.50\end{array}$ & $\begin{array}{l}1.40 \\
2.20\end{array}$ & $\begin{array}{l}\mathbf{1 . 9 0} \\
\mathbf{3 . 0 0}\end{array}$ & $\begin{array}{l}\mathbf{2 . 4 0} \\
\mathbf{3 . 8 0}\end{array}$ & $\begin{array}{l}\mathbf{5 . 5 0} \\
\mathbf{8 . 7 5}\end{array}$ \\
\hline $\begin{array}{l}\text { VERY LATE STRAWBERRIES } \\
\text { Aroma } \\
\text { Brandy wine } \\
\text { Pearl }--1\end{array}$ & & $\begin{array}{l}.75 \\
.60 \\
.90\end{array}$ & $\begin{array}{r}1.00 \\
.75 \\
1.20\end{array}$ & $\begin{array}{r}1.20 \\
1.95\end{array}$ & $\begin{array}{l}1.75 \\
1.40 \\
\mathbf{2 . 1 5}\end{array}$ & $\begin{array}{l}2.40 \\
1.90 \\
\mathbf{2 . 9 5}\end{array}$ & $\begin{array}{l}\mathbf{3 . 0 0} \\
\mathbf{2 . 4 0} \\
\mathbf{3 . 7 0}\end{array}$ & $\begin{array}{l}\mathbf{7 . 0 0} \\
\mathbf{5 . 5 0} \\
\mathbf{8 . 5 0}\end{array}$ \\
\hline $\begin{array}{l}\text { EVERBEARING STRAWBERRIES } \\
\text { Progressive }-19 \text { plants for } 70 \mathrm{c}, 7.1\end{array}$ & & $\begin{array}{l}.20 \\
.95\end{array}$ & $\begin{array}{l}\text { 1.50 } \\
\mathbf{2 . 6 0}\end{array}$ & $\begin{array}{l}\text { 2.00 } \\
\text { 3.00 }\end{array}$ & $\begin{array}{l}2.80 \\
5.15\end{array}$ & $\begin{array}{l}\mathbf{3 . 8 0} \\
6.80\end{array}$ & $\begin{array}{l}4.80 \\
8.25\end{array}$ & $\begin{array}{l}11.00 \\
20.00\end{array}$ \\
\hline 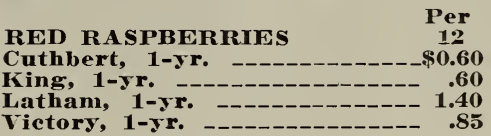 & $\begin{array}{l}\text { Per } \\
25 \\
\$ 1.00 \\
.95 \\
2.20 \\
1.50\end{array}$ & $\begin{array}{l}\text { Per } \\
50 \\
\$ 1.90 \\
1.70 \\
\mathbf{3 . 8 0} \\
\mathbf{2 . 7 5}\end{array}$ & $\begin{array}{lc}\mathbf{P}=\mathbf{r} \\
\mathbf{7 5} \\
\mathbf{5 2 . 5 0} \\
\mathbf{9 2 . 3 0} \\
\mathbf{2 . 5 0} \\
\mathbf{5 . 4 0} \\
\mathbf{5} & \mathbf{3 . 5 0}\end{array}$ & $\begin{array}{l}\text { Per } \\
100 \\
\$ 3.00 \\
2.80 \\
7.00 \\
4.25\end{array}$ & $\begin{array}{r}\text { Per } \\
200 \\
\$ 4.50 \\
4.00 \\
11.00 \\
6.25\end{array}$ & $\begin{array}{r}\text { Per } \\
\mathbf{3 0 0} \\
\mathbf{\$ 6 . 1 5} \\
\mathbf{5 . 5 0} \\
\mathbf{1 4 . 5 0} \\
\mathbf{8 . 7 5}\end{array}$ & $\begin{array}{r}\text { Per } \\
400 \\
\$ 7.80 \\
6.90 \\
17.60 \\
11.00\end{array}$ & $\begin{array}{c}\text { Per } \\
\mathbf{1 0 0 0} \\
\$ 18.00 \\
\mathbf{1 6 . 0 0} \\
\mathbf{4 0 . 0 0} \\
\mathbf{2 5 . 0 0}\end{array}$ \\
\hline 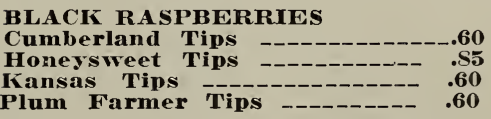 & $\begin{array}{l}1.00 \\
1.50 \\
1.00 \\
1.00\end{array}$ & $\begin{array}{l}1.90 \\
2.75 \\
1.90 \\
1.90\end{array}$ & $\begin{array}{l}\mathbf{2 . 5 0} \\
\mathbf{3 . 5 0} \\
\mathbf{2 . 5 0} \\
\mathbf{2 . 5 0}\end{array}$ & $\begin{array}{r}\mathbf{3 . 0 0} \\
\mathbf{4 . 2 5} \\
\mathbf{3 . 0 0} \\
\mathbf{3 . 0 0}\end{array}$ & $\begin{array}{l}4.50 \\
6.25 \\
4.50 \\
4.50\end{array}$ & $\begin{array}{l}6.15 \\
8.75 \\
6.15 \\
6.15\end{array}$ & $\begin{array}{r}7.80 \\
11.00 \\
7.80 \\
7.80\end{array}$ & $\begin{array}{l}18.00 \\
25.00 \\
18.00 \\
18.00\end{array}$ \\
\hline $\begin{array}{l}\text { BLACIKBERRIES \& DEWBERRIES } \\
\text { Alfred Blackberry R. C. }-\overline{1.65} \\
\text { Eldorado Root Cutting Plants } \\
\text { Mersereau Blackberry R. C. }- \\
\text { Lucretia Dewberry Tips }--.85 \\
\end{array}$ & $\begin{array}{l}3.00 \\
1.35 \\
1.50 \\
1.00\end{array}$ & $\begin{array}{l}\mathbf{5 . 5 0} \\
2.50 \\
2.75 \\
1.90\end{array}$ & $\begin{array}{l}7.00 \\
\mathbf{3 . 1 5} \\
\mathbf{3 . 5 0} \\
2.50\end{array}$ & $\begin{array}{l}8.25 \\
4.00 \\
4.25 \\
3.00\end{array}$ & $\begin{array}{r}12.50 \\
6.10 \\
6.25 \\
4.50\end{array}$ & $\begin{array}{r}17.50 \\
8.00 \\
8.75 \\
6.15\end{array}$ & $\begin{array}{r}22.00 \\
9.90 \\
11.00 \\
7.80\end{array}$ & $\begin{array}{l}\mathbf{5 0 . 0 0} \\
212.50 \\
\mathbf{2 5 . 0 0} \\
\mathbf{1 8 . 0 0}\end{array}$ \\
\hline $\begin{array}{l}\text { Iartha Washington, } 1-y \mathbf{r}, \text { No.1 } \\
\text { Iartha Washington, } 2-\text { yr.,No.1 } \\
\end{array}$ & $\begin{array}{l}.50 \\
.70\end{array}$ & $\begin{array}{l}1.00 \\
1.30\end{array}$ & $\begin{array}{l}1.25 \\
1.65\end{array}$ & $\begin{array}{l}1.50 \\
2.00\end{array}$ & $\begin{array}{l}2.25 \\
3.00\end{array}$ & $\begin{array}{l}\mathbf{3 . 1 0} \\
\mathbf{4 . 1 0}\end{array}$ & $\begin{array}{l}\mathbf{3 . 9 0} \\
5.20\end{array}$ & $\begin{array}{r}9.00 \\
12.00\end{array}$ \\
\hline
\end{tabular}

\section{THE BALDWIN GUARANTEE-Your Assurance of Satisfaction}

We guarantee every plant, tree, shrub, or bulb sold by us to be first class in every way, free from any injurious disease or insect, and absolutely true-toname.

We further guarantee our stock to reach the customer in good growing condition by mail or express and will replace free of charge any that does not; providing claim is immediately made and express receipt and signed statement of postmaster or express agent showing amount of loss or damage, is returned therewith.

Furthermore, we will, on proper proof, replace free of charge or refund the purchase price of any stock that proves untrue-to-name. In no case will we be liable for more than the original purchase price of stock. 


\section{ORDER SHEET \\ Warren Gladiolus Gardens James G. Warren \\ P. O. Box 38, Frankfort, Indiana}

Ship to

Please write your name plainly

Street and No.

Postoffice

Express Office

When to ship
Date

P. O. Box

or R. F. D.

State

May we substitute if out of the variety or size you order?

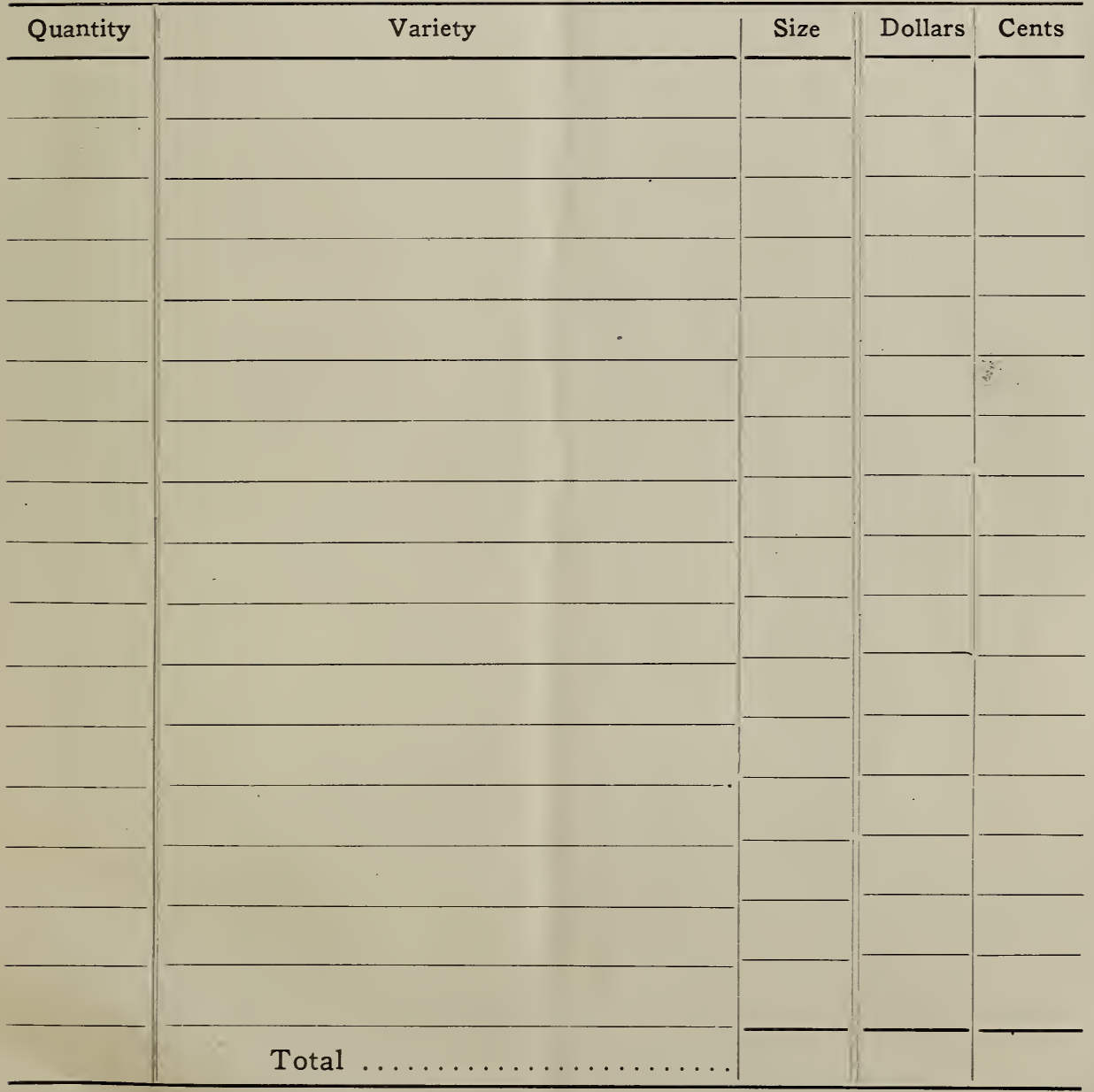

Write letter on separate sheet. Keep a copy of your order. 


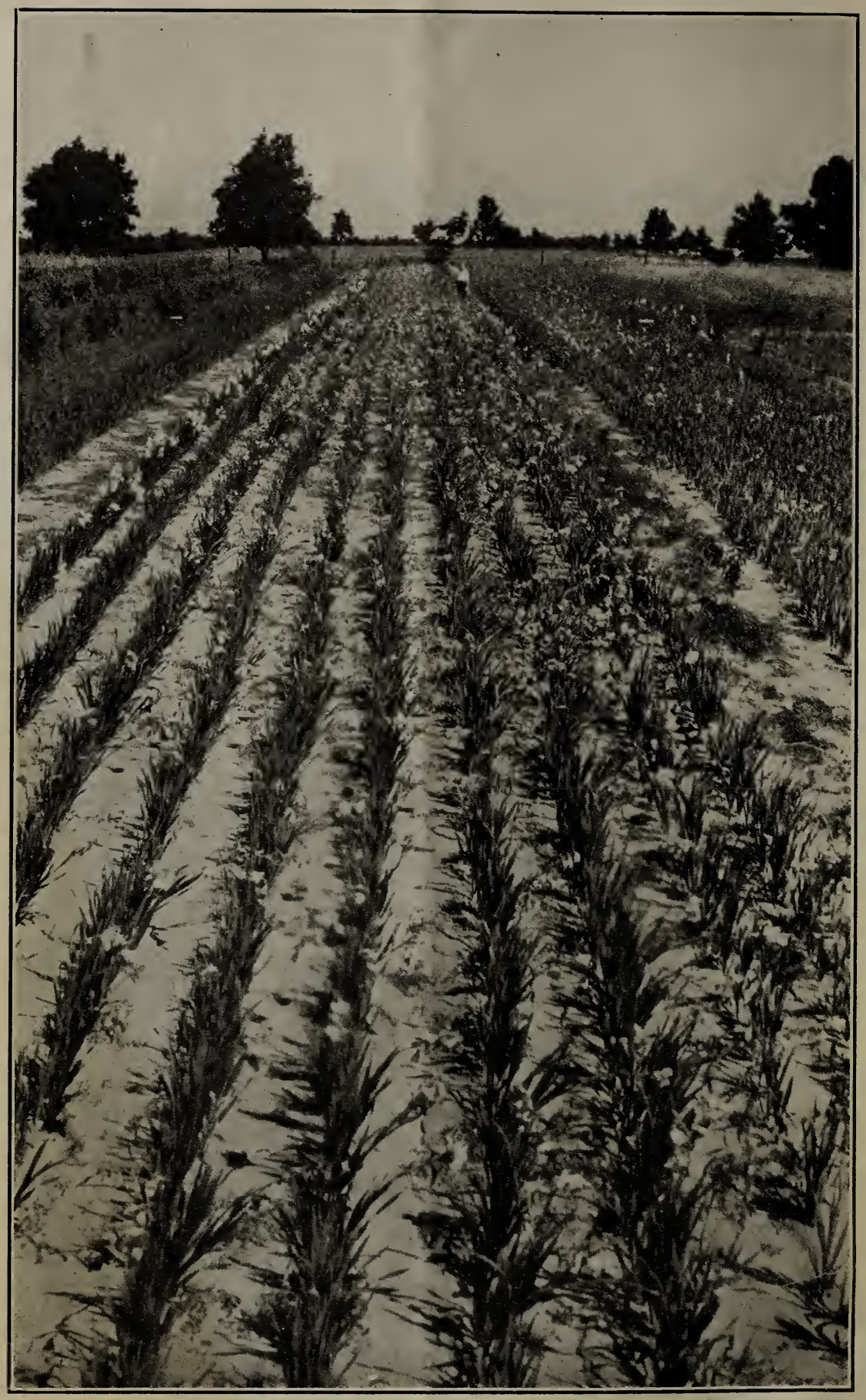

A FIELD OF GLADIOLUS IN MIDSUMMER 